\title{
Understanding mental disorders from neuronal networks to glial cells and proteomics
}

\author{
Peter Falkai · Hans-Jürgen Möller
}

(C) The Author(s) 2010. This article is published with open access at Springerlink.com

Dear colleagues,

In the current issue of the European Archives of Psychiatry and Clinical Neuroscience, we have tried to bring together a number of interesting articles analysing the pathophysiology of mental disorders on different levels of distinction.

Looking for the neural correlates of aversive conditioning, Reinhardt et al. [1] are searching for a functional imaging paradigm to investigate a basis of anxiety disorders. Likewise searching for a suitable phenotype of disturbed neuronal development, several research groups have focussed on the analysis of gyral pattern. A number of studies on schizophrenia and mayor affective disorders have described changes in this respect. The current paper by Wobrock et al. [2] analyses the gyrification pattern in patients with obsessive-compulsive disorder adding another aspect to this discussion.

Going from global to regional networks, Suga et al. [3] search for the association between several Brodmann areas and psychopathological abnormalities and reveal a correlation between Brodmann's Area 45 and the prevalence of psychotic symptoms in schizophrenia.

Neuronal networks are based on the function not only of neurons but several other entities like glial cells and the neuropil. For a long time, glial cells have been regarded the

P. Falkai $(\bowtie)$

Department of Psychiatry and Psychotherapy,

University of Göttingen, von-Siebold-Str. 5,

37075 Göttingen, Germany

e-mail: pfalkai@gwdg.de

H.-J. Möller

Psychiatry Hospital, Ludwigs-Maximilians-University Munich,

Nussbaumstr. 7, 80336 Munich, Germany glue of the brain subserving functions of the neuronal cells. Intensive research in the last years has shown us that they are pivotal for the functioning of the neuronal network in themselves. Therefore, researching the effects of neuroleptic treatment on glial functions as has been done in the next paper by Quincozes-Santos et al. [4] is of utmost importance to understand the beneficial as well as negative effects of these substances on the human brain. A direct way of researching the effects of risk genes e.g. the 5HTTLPR on cellular components of the blood and the connected serotonergic system has been used in patients with anorexia nervosa by Ehrlich et al. [5].

Another way of researching elements of the neuronal network is the targeted use of electrophysiology. In the next paper [6], auditory mismatch negativity was researched in heavy Cannabis users pointing at a dysfunction of inhibitory elements of the brain e.g. the glutamatergic and cholinergic subsystems.

Neuronal networks and their individual elements express pattern of proteins which can be visualised using proteomic analysis. Furthermore, recently very sophisticated ways of analysing specific compartments of the human brain have been developed. Therefore, it is important to discuss the possibilities but also the limitations of proteome analyses in the research of major psychiatric disorders, as Martins-de-Souza et al. [7] show in their paper.

Psychiatric research is characterised by a multitude of methods and research topics. It is important to understand the possibilities of these methods to judge the relevance of the gained results. This issue tries to give examples of researching key issues of brain dysfunction in mental disorders on different levels of distinction. 2010
H.-J. Möller (München) P. Falkai (Göttingen) 16 August 
Open Access This article is distributed under the terms of the Creative Commons Attribution Noncommercial License which permits any noncommercial use, distribution, and reproduction in any medium, provided the original author(s) and source are credited.

\section{References}

1. Reinhardt I, Jansen A, Kellermann T, Schüppen A, Kohn N, Gerlach AL, Kircher T (2010) Neural correlates of aversive conditioning: development of a functional imaging paradigm for the investigation of anxiety. Eur Arch Psychiatry Clin Neurosci. doi:10.1007/s00406-010-0099-9

2. Wobrock T, Gruber O, McIntosh AM, Kraft S, Klinghardt A et al. (2010) Reduced prefrontal gyrification in obsessive-compulsive disorder. Eur Arch Psychiatry Clin Neurosci. doi:10.1007/s00406009-0096-Z

3. Suga M, Yamasue H, Abe O, Yamasaki S, Yamada H (2009) Reduced gray matter volume of Brodmann's Area 45 is associated with severe psychotic symptoms in patients with schizophrenia. Eur Arch Psychiatry Clin Neurosci. doi:10.1007/s00406-0090094-1

4. Quincozes-Santos A, Bobermin LD, Tonial RP, Bambini-Junior V, Riesgo R and Gottfried C (2009) Effects of atypical (risperidone) and typical (haloperidol) antipsychotic agents on astroglial functions. Eur Arch Psychiatry Clin Neurosci. doi:10.1007/s00406-009-0095-0

5. Ehrlich S, Franke L, Scherag S, Burghardt R, Schott R et al. (2009) The 5-HTTLPR polymorphism, platelet serotonin transporter activity and platelet serotonin content in underweight and weight-recovered females with anorexia nervosa. Eur Arch Psychiatry Clin Neurosci. doi:10.1007/s00406-009-0092-3

6. Roser P, Della B, Norra C, Uhl I, Brüne M, Juckel G (2010) Auditory mismatch negativity deficits in long-term heavy cannabis users. Eur Arch Psychiatry Clin Neurosci. doi:10.1007/s00406010-0097-y

7. Martins-de-Souza D, Harris LW, Guest PC, Turck CW, Bahn S (2009) The role of proteomics in depression research. Eur Arch Psychiatry Clin Neurosci. doi:10.1007/s00406-009-0093-2 